\title{
ANALISIS SPEKTROFOTOMETRI TERHADAP GUGUS FUNGSI EKSTRAK METANOL RUMPUT LAUT Ulva fasciata SEGAR DAN KERING MATAHARI
}

\author{
Hedi Indra Januar, Thamrin Wikanta, dan Emma Hastarini")
}

\begin{abstract}
ABSTRAK
Riset ini dilaksanakan untuk mengetahui efek penggunaan sinar matahari sebagai metode preparasi bahan baku terhadap gugus fungsional di dalam ekstrak metanol rumput laut Ulva fasciata. Hasil analisis yang didasarkan pada metode spektrofotometri UV-Vis menunjukkan bahwa terjadi penurunan absorbansi pada panjang gelombang $240-270 \mathrm{~nm}$, yang merupakan daerah ikatan rangkap terkonjugasi. Sementara spektrofotometri FT-IR menunjukkan terjadinya penurunan konsentrasi gugus fungsional yang mempunyai pita pada $1111,25 \mathrm{~cm}^{-1}$ (C-O) dan $1406,63 \mathrm{~cm}^{-1}(\mathrm{C}=\mathrm{C})$, serta kenaikan konsentrasi gugus fungsional pada $1639 \mathrm{~cm}^{-1}(\mathrm{C}=0)$ selama 48 jam pengeringan bahan baku. Hasil ini membuktikan bahwa proses pengeringan matahari sebagai metode preparasi sampel sebaiknya dihindarkan pada eksplorasi senyawa alami dari rumput laut Ulva fasciata.

$\begin{array}{ll}\text { ABSTRACT: } & \text { Spectrophotometry analysis on functional groups in methanolic extract of } \\ & \text { fresh and sun dried seaweed Ulva fasciata. By: Hedi Indra Januar, Thamrin } \\ & \text { Wikanta, and Emma Hastarini }\end{array}$

This research was aimed to observe the effect of raw material sun drying on the functional groups of fresh UIva fasciata extract. The result based on UV-Vis spectrophotometry analysis showed that there was an absorbance reduction at 240-270 nm, which is an area for double conjugated bonds. On the other hand, FT-IR spectrophotometry did not only detect a reduction of functional groups concentration that has bands at $1111.25 \mathrm{~cm}^{-1}(C-O)$ and $1406.63 \mathrm{~cm}^{-1}(C=C)$, but also some increment $(C=0)$ at $1639 \mathrm{~cm}^{-1}$ during 48 hours of sun drying process. These results proved that sun drying process as a sample preparation method should be avoided in natural substances exploration of Ulva fasciata.
\end{abstract}

KEYWORDS: Ulva fasciata, methanolic extract, raw material preparation

\section{PENDAHULUAN}

Aspek terpenting dalam ekplorasi senyawa bioaktif dari rumput laut adalah preparasi sampel yang tepat. Secara umum, proses pengeringan bahan baku dilakukan sebelum pelaksanaan ekstraksi untuk meningkatkan efisiensi penanganan sampel. Pada tumbuhan darat yang memiliki kadar air rendah, proses ini biasanya dilaksanakan dengan meniupkan angin pada suhu ruang. Namun, pada rumput laut hal ini tidak dapat dilaksanakan karena tingginya kadar air laut yang merupakan medium kaya nutrisi untuk bakteri, hingga dapat membuat sampel menjadi busuk. Untuk menghindari hal tersebut, Anggadiredja (2004) yang melakukan riset eksplorasi senyawa antibakteri dari rumput laut melaksanakan pengeringan sampel menggunakan sinar matahari seperti pada aplikasi dalam ekstraksi senyawa metabolit primer seperti agaragar, karaginan, dan juga alginat. Proses ini memiliki keunggulan dalam efisiensi penanganan pengambilan sampel dan aplikasi industri.

Namun, baik pada metode maupun pembahasannya Anggadiredja (2004) tidak memberikan penjelasan apakah proses pengeringan menggunakan sinar matahari, sinar ultraviolet dengan intensitas energi yang tinggi, tidak akan merusak struktur senyawa bioaktif yang terdapat di dalam sampel. Walaupun sampel rumput laut kering akan lebih efisien dan praktis dalam proses preparasi ekstraksi rumput laut, akan tetapi menjaga keaslian senyawa dalam eksplorasi bahan bioaktif alami jauh lebih penting untuk mendapatkan validitas senyawa dan bioaktivitas senyawa yang ditemukan. Hashimoto (1979) menerangkan bahwa pengeringan spesimen menggunakan sinar matahari harus dihindarkan karena toksisitas alga akan terdekomposisi jika teradiasi oleh sinar ultraviolet. la juga mengemukakan bahwa setengah toksisitas alga tersebut akan hilang

\footnotetext{
-) Peneliti pada Pusat Riset Pengolahan Produk dan Sosial Ekonomi Kelautan dan Perikanan
} 
jika dirádiasi oleh smar ultraviolet selama tiga jam. Lebih lanjut, Stanley et al (1988) menyatakan bahwa kerusakan bahan organik yang dihadapkan ke sinar matahari dalam medium udara terjadi karena reaksi fotooksidasi yang dipicu oleh adanya cahaya Namun, disini tidak dijelaskan juga seberapa jauh perubahan yang terjadi secara kuantitatif

Oleh karena itu, riset ini bertujuan untuk mengetahui apakah terjadi perubahan konsentrasi senyawa di dalam rumput laut selama proses pengeringan bahan baku menggunakan sinar matahari Hal ini dilakukan dengan membandingkan konsentrasi gugus-gugus aktif di dalam ekstrak rumput laut yang berasal dari preparasi bahan baku segar dan bahan baku yang dikeringkan dengan sinar matahari. Gugus-gugus aktif, yaitu ikatan rangkap pada rantai karbon dan gugus fungsi, dipilih sebagai parameter pengamatan karena perannya yang penting di dalam reaksi kimia dan menentukan bioaktivitas dari senyawa tersebut. Oleh karena itu, hasil perbandingan spektrofotometri dari gugus-gugus aktif pada eksrak yang berasal dari bahan baku segar dan kering matahari dapat dijadikan sebagai bahan rekomendasi apakah proses pengeringan dengan sinar mataharı dapat dilakukan atau tidak

Sebagai subjek penelitian, dipilih rumput laut UIva fasciata. Flora laut ini merupakan salah satu jenis rumput laut dengan bioaktivitas yang baik Febles et al. (1995) menerangkan bahwa Ulva fasciata mempunyai senyawa aktif antimikroba dalam fraksi polarnya, yaitu fraksi metanol. Hal ini didukung oleh eksplorasi bahan antimikroba yang dilakukan oleh Portito \& Reina (2001) pada berbagai jenis alga di Canary Islands, Spanyol, yang juga menemukan bahwa ekstrak metanol alga Ulva sp memilikiaktivitas antimikroba terhadap bakteri Staphylococcus aureus MB5393, Bacillus subtilis MB954 dan fungi Aspergillus fumigatus MF5668. Hashimoto (1979), berhasil mengisolasi senyawa-senyawa turunan klorofil larut air yang berupa aldehida dan mempunyai aktıvitas sebagai antibakteri. Oleh karena itu, pengamatan tentang gugus aktif pada senyawa di dalam ekstrak Ulva fasciata akan difokuskan terhadap ekstrak metanol.

\section{BAHAN DAN METODE}

\section{Persiapan Ekstrak Sampel}

Prosedur ekstraksi dilakukan seperti yang dilaporkan oleh Vitor et al (2002). UIva fasciata segar sebanyak $2 \mathrm{~kg}$ diambil pada bulan Agustus 2003 di Pantai Baron Gunung Kidul, Yogyakarta. Sampel segar sebanyak $1 \mathrm{~kg}$ langsung dimaserasi menggunakan $800 \mathrm{ml}$ metanol. Sisa dari sampel yang diambil dikeringkan di bawah sinar matahari selama 48 jam, ditimbang, lalu dimaserasi menggunakan 800 $\mathrm{ml}$ pelarut metanol. Setelah 48 jam, pelarut disaring, lalu residu ditambahkan kembali dengan metanol. Hal ini dilakukan sebanyak dua kali hingga total pelarut metanol yang digunakan sebanyak 2400 ml. Larutan dievaporasi hingga mencapai volume $250 \mathrm{ml}$. Fraksi metanol kemudian dibebaskan dari senyawa berkepolaran rendah, masing-masing menggunakan $250 \mathrm{ml}$ pelarut kloroform dan n-heksana sebanyak 3 kali. Fraksi metanol dievaporasi kembali hingga mencapal volume sekecil mungkin dan dikeringkan menggunakan freeze dryer (pengering beku). Deteksi gugus-gugus aktif dalam ekstrak metanol dilaksanakan seperti yang dilaporkan oleh Hashimoto (1979) yaitu menggunakan spektrofotometer Uitra Violet-Visible (UV-Vis) dan Fourier Transfer-Infra Red (FT-IR)

\section{Analisis Spektrum UV-Vis}

Analisis dengan spektrofotometer UV-Vis (Perkin Elmer Lambda 25) dilakukan dengan melarutkan masing-masing sampel ekstrak metanol dari bahan baku segar dan kering matahari yang sudah dikeringkan dengan freeze dryer sebanyak $1 \mathrm{mg}$ dalam $20 \mathrm{ml}$ metanol (50 ppm). Sampel ini kemudian diuji serapan sinar UV-Vis pada panjang gelombang 190$1100 \mathrm{~nm}$ mempergunakan blanko metanol pada kuvet quartz $10 \mathrm{~mm}$

\section{Analisis Spektrum FT-IR}

Analisis dilakukan terhadap masing-masing sampel dengan perbandingan yang sama, yaitu $\mathrm{KBr}$ : sampel = $200 \mathrm{mg} 5 \mathrm{mg}$. menggunakan FT-IR (Perkin Elmer Spectrum One) pada bilangan gelombang 4000$450 \mathrm{~cm}^{-1}$, scan number 6 dan scan speed $0,2 \mathrm{~cm} / \mathrm{s}$, resolusi $4 \mathrm{~cm}^{-1}$.

\section{HASIL DAN BAHASAN}

Ulva fasciata segar sebanyak $1 \mathrm{~kg}$ pada saat kering matahari menjadi $200 \mathrm{~g}$. Hasil ini memperlihatkan bahwa berat yang hilang adalah $80 \%$ dari berat awal selama pengeringan sinar matahari 48 jam Sebagian besar berat yang hilang berasal dari kadar air. Namun, kehilangan sejumlah massa yang akan diperlihatkan dalam hasil penelitian juga menambah berat yang hilang. Hasil analisis spektrum UV-Vis dan FT-IR dapat dilihat pada Gambar 1 dan 3

Spektrum UV-Vis memperlihatkan serapan absorbansi yang hampir sejajar, terkecuali pada daerah sinar ultraviolet antara 240-270 nm, yang merupakan daerah ikatan rangkap. Perbedaan intensitas absorbansi sinar ultraviolet terhadap ikatan 


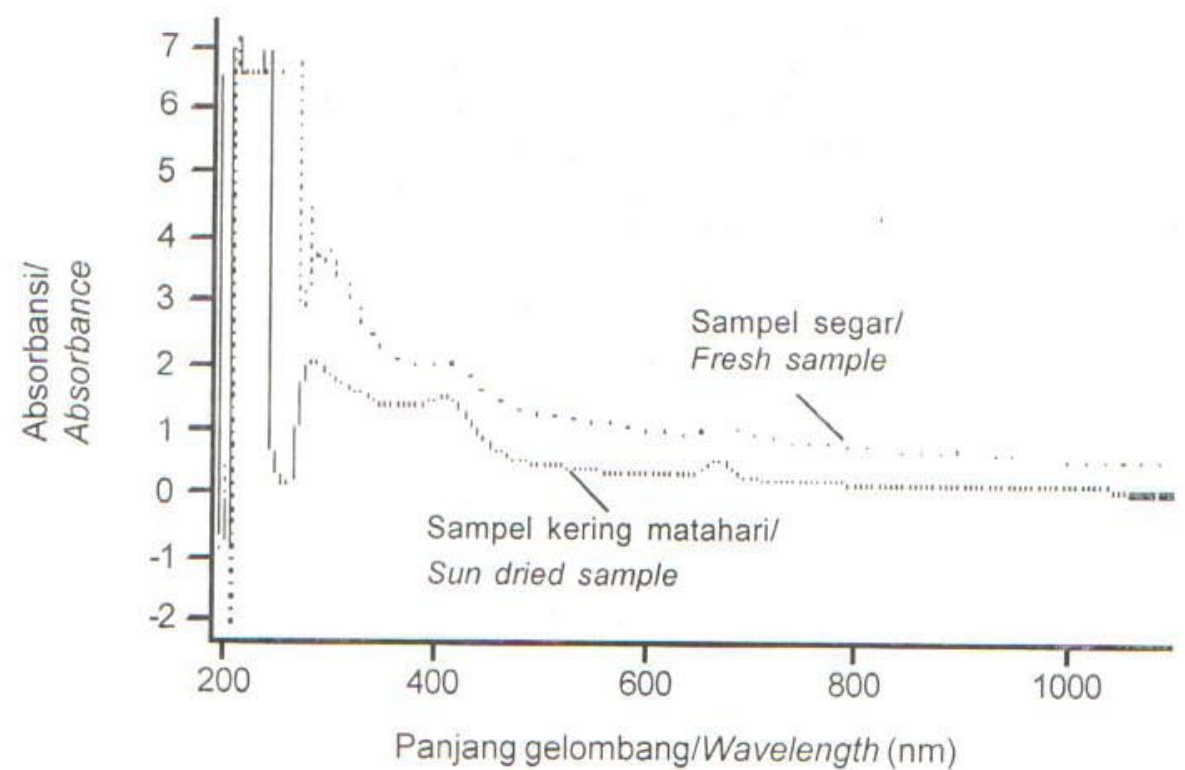

Gambar 1. Spektrum UV-Vis ekstrak metanol Ulva fasciata dari bahan baku segar dan kering matahari. Figure 1. UV-Vis spectra of methanolic extract from fresh and sun dried UIva fasciata.

rangkap terkonjugasi antara sampel segar dan kering matahari menunjukkan adanya perubahan konsentrasi ikatan rangkap dua terkonjugasi yang terjadi selama proses pengeringan. Hal ini berdasarkan Hukum Lambert-Beer yang menerangkan hubungan antara daya radiasi yang diserap sampel (Po) dan daya radiasi yang dilepaskannya dan dideteksi oleh detektor $(P)$ (Willard et al., 1974), seperti pada persamaan (1). Tetapan Log[Po/P] spektrofotometri UV-Vis dapat dinyatakan sebagai absorbansi (Willard et al., 1974). Oleh karena itu, persamaan (1) menerangkan bahwa absorbansi berbanding lurus dengan konsentrasi (C).

$$
\log [\mathrm{Po} / \mathrm{P}]=k \mathrm{C}
$$

\section{Keterangan/Note : \\ $k$ : tetapan/constant \\ C : konsentrasi/concentration}

Perubahan penyerapan sinar UV-Vis pada tiap panjang gelombang dari 190-1000 nm oleh sampel segar dan sampel kering matahari menghasilkan grafik pada Gambar 2.

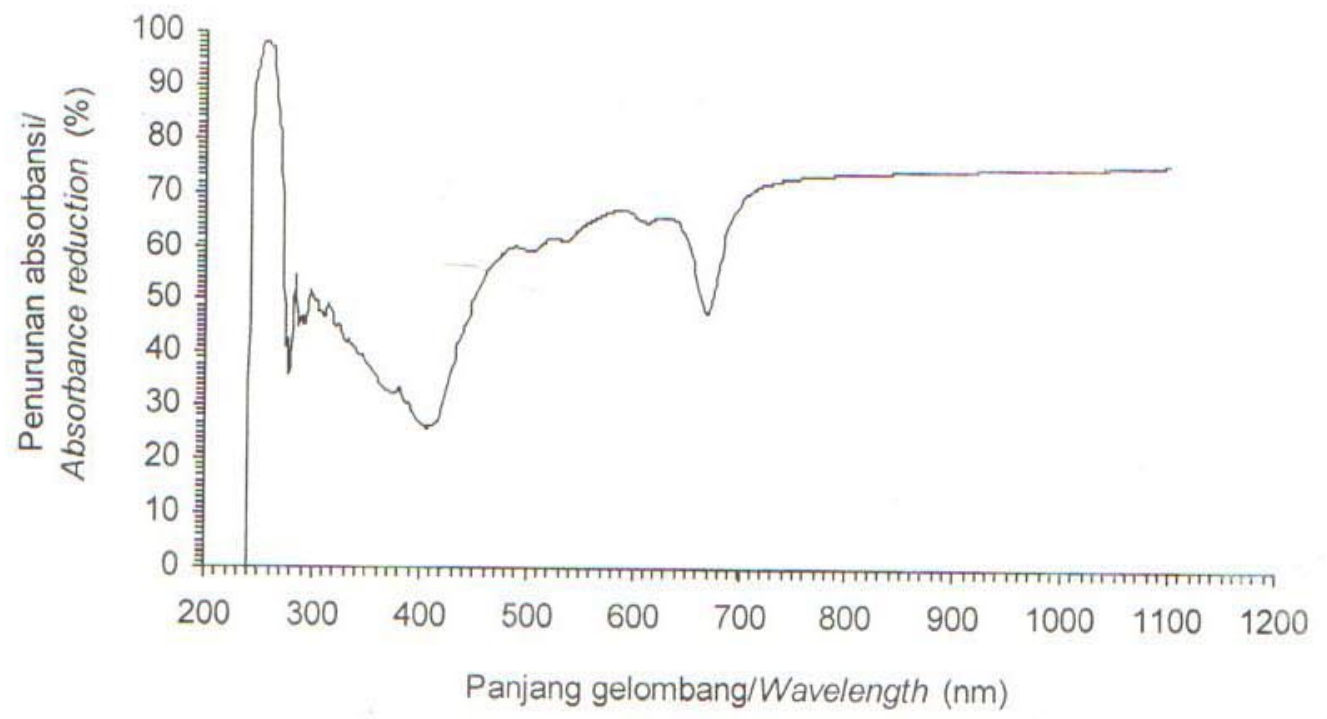

Gambar 2. Perubahan intensitas absorbansi gelombang ultraviolet-sinar tampak dari sampel segar ke sampel kering matahari.

Figure 2. Changing absorbance intensity UV-Vis wavelength from fresh sample to sun dried sample. 
Grafik pada Gambar 2 memperlihatkan bahwa daerah yang mengalami perubahan tertinggi adalah daerah panjang gelombang antara 240-270 nm, yaitu daerah penyerapan gugus-gugus rangkap terkonjugasi, seperti konjugasi linear, dan sikloheksana yang mempunyai rantai samping ikatan rangkap terkonjugasi.

Serupa dengan spektrum UV-Vis, spektrum FT-IR sampel segar dan sampel kering matahari memperlihatkan pita yang sama dan sejajar. Interpretasi data spektrum FT-IR ini didasarkan Silverstain et al. (1986). Pita spektrum memperlihatkan adanya beberapa gugus fungsional yang bertumpang tindih di daerah bilangan gelombang yang berdekatan. Rentang bilangan gelombang lebar di $3000-3500 \mathrm{~cm}^{-1}$ yang merupakan gugus hidroksil karbonil $(\mathrm{C}=\mathrm{O}$ ). Letak bilangan gelombangnya yang bergeser menjadi lebih rendah dari bilangan gelombang karbonil yang normal $\left(1715 \mathrm{~cm}^{-1}\right)$ diakibatkan adanya tumpang tindih dengan tekukan $\mathrm{N}$-H dari amida sekunder sederhana berantai terbuka. Selain itu bilangan gelombang ini juga dapat menunjukkan adanya uluran ikatan konjugasi yang simetris. Bilangan gelombang $1406,63 \mathrm{~cm}^{-1}$ memperlihatkan adanya tekukan gugus olefinik di dalam bidang dan tekuk C-H di dalam bidang. Uluran ikatan oksigen dari eter (R-O-R) terlihat pada pita $1111,25 \mathrm{~cm}^{-1}$ Keberadaan gugus hidroksil kemudian diperkuat dengan adanya tekukan ikatan hidrogen dari gugus hidroksil keluar bidang di $625 \mathrm{~cm}^{1}$

Perhitungan kosentrasi gugus aktif pada spektrum FT-IR juga didasarkan pada hukum Lambert-Beer,

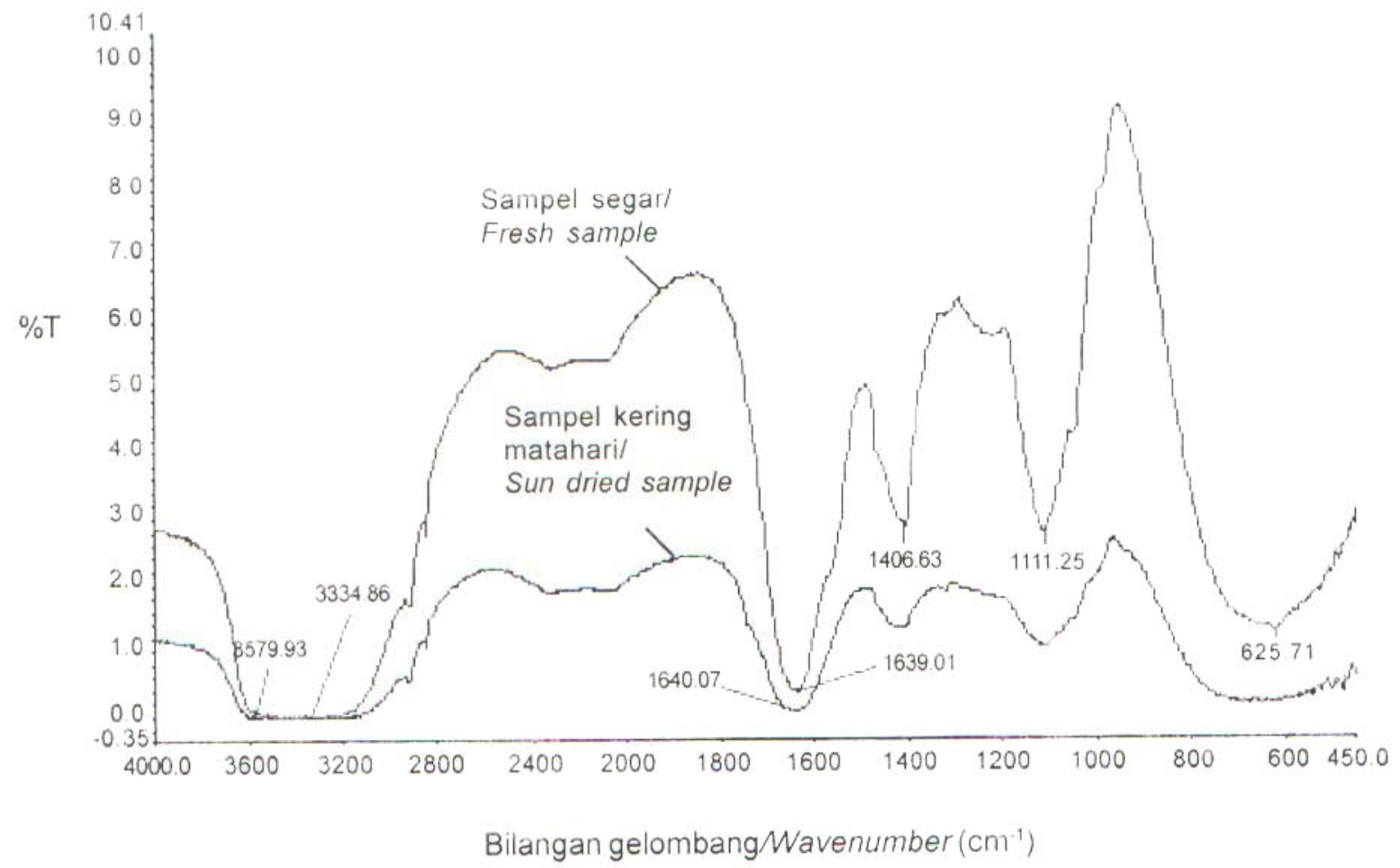

Gambar 3. Spektrum FT-IR ekstrak metanol Ulva fasciata dari ekstrak sampel segar dan kering matahari. Figure 3. FT-IR spectra of methanolic extract Ulva fasciata from fresh and sun dried sample.

berikatan dengan hidrogen dan vibrasi ulur $\mathrm{N}-\mathrm{H}$ dari amida yang juga berikatan hidrogen. Pada bilangan gelombang 2800-2900 $\mathrm{cm}^{-1}$ menunjukkan adanya vibrasi ulur gugus metilen $\left(\mathrm{CH}_{2}\right)$. Walaupun lemah, daerah bilangan gelombang antara $2000 \mathrm{~cm}^{-1}$ sampai $2400 \mathrm{~cm}^{-1}$ memperlihatkan vibrasi ulur pita kombinasi $\mathrm{N}-\mathrm{H}$ pada $2140 \mathrm{~cm}^{-1}$ dan selanjutnya pada $2300 \mathrm{~cm}^{-1}$ sebagai kombinasi nada lipat lainnya. Bilangan gelombang $1639 \mathrm{~cm}^{-1}$ yang merupakan pita yang tajam dan kuat, dikenali sebagai gugus fungsional namun perhitungannya tidak seperti pada spektrum UV-Vis yang dilakukan dengan membandingkan absorbansinya. Perhitungan pada spektrum FT-IR di antaranya dilakukan dengan membandingkan nilai log $[\mathrm{Po} / \mathrm{P}]$ dari tiap-tiap pitanya. Nilai log $[\mathrm{Po} / \mathrm{P}]$ pada spektrum infra merah tidak sebanding dengan nilai absorbansinya (Willard et al., 1974). Analisis lanjut dilakukan terhadap tiga bilangan gelombang utama dari ekstrak yaitu pada bilangan gelornbang 1111,25 $\mathrm{cm}^{-1}, 1406,63 \mathrm{~cm}^{-1}$, dan $1639 \mathrm{~cm}^{-1}$ yang didasarkan 


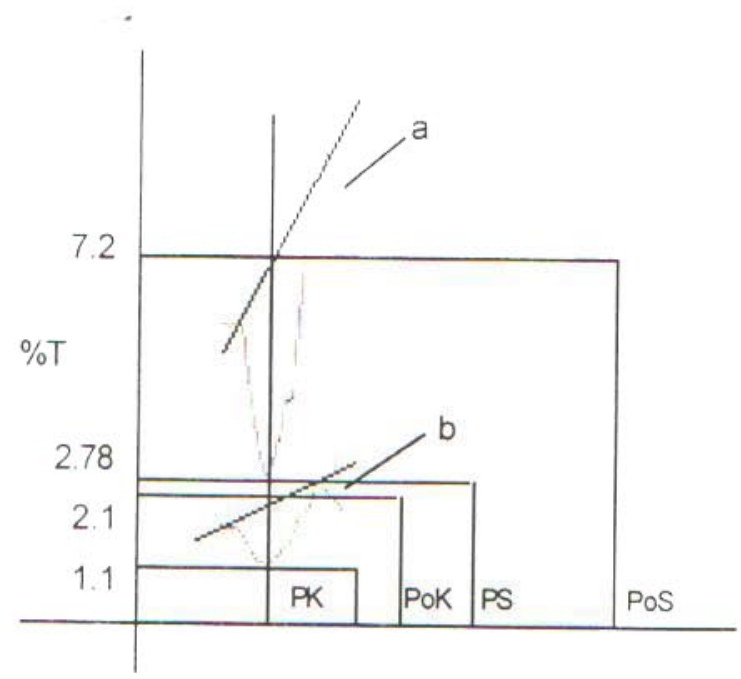

Bilangan gelombang/Wavenumber $1111.25 \mathrm{~cm}^{-1}$

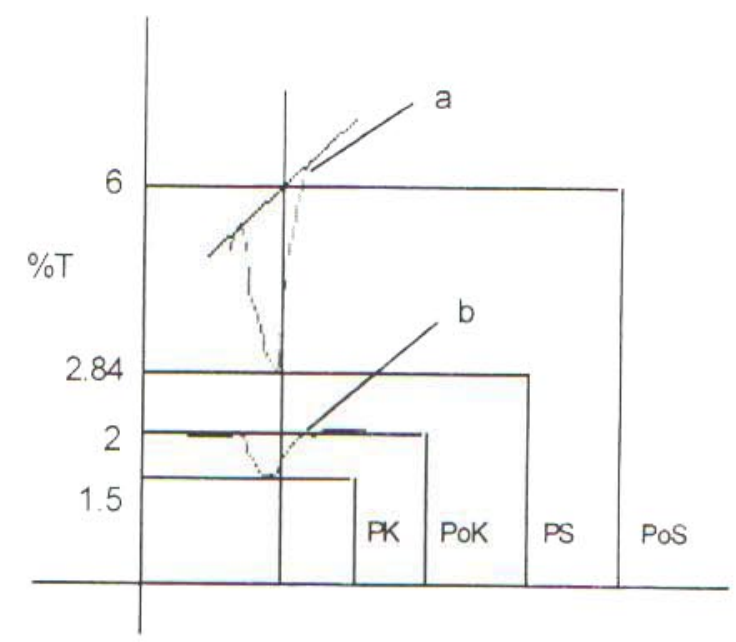

Bilangan gelombang/Wavenumber $1406.63 \mathrm{~cm}^{-1}$

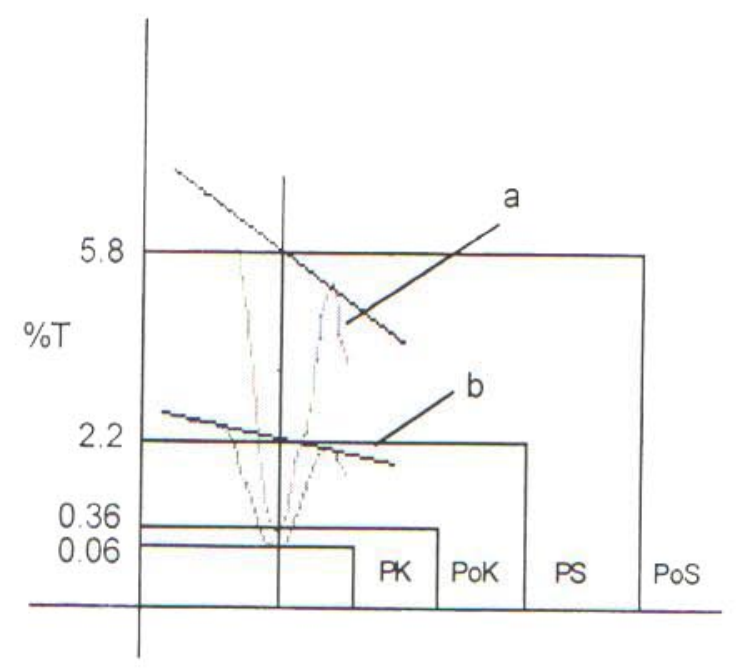

Bilangan gelombang/Wavenumber $1639 \mathrm{~cm}^{-1}$

\section{Keterangan/Note}

a : Spektrum sampel segar/Fresh sample spectra

b : Spektrum sampel kering/Dried sample spectra

PK : P sampel kering/P of dried sample

PS : P sampel segar/P of fresh sample

PoK : Po sampel kering/Po of dried sample

PoS: Po sampel segar/Po of fresh sample

Gambar 4. Po dan P dari bilangan gelombang $1111,25 \mathrm{~cm}^{-1}, 1406,63 \mathrm{~cm}^{-1}$ dan $1639 \mathrm{~cm}^{-1}$ pada spektrum FT-IR ekstrak metanol Uiva fasciata segar dan kering matahari.

Figure 4. Po and $P$ of wavenumber at $1111.25 \mathrm{~cm}^{-1}, 1406.63 \mathrm{~cm}^{-1}$ and $1639 \mathrm{~cm}^{-1}$ in FT-IR spectrum of methanolic extract from fresh and sun dried Ulva fasciata. 
pada metode perhitungan Willard et al. (1974). Titik Po dan $P$ pada masing-masing pita karakteristik terlihat pada Gambar 4.

Hasil perhitungan rasio perubahan konsentrasi yang terjadi pada ketiga bilangan gelombang di atas dapat dilihat pada Tabel 1. Rasio dihitung dari persentase log sampel kering per sampel segar.

Spektrum UV-Vis dan FT-IR untuk sampel segar dan kering memperlihatkan pola yang sama dengan perbedaan intensitas. Hal ini dapat menimbulkan pertanyaan apakah penurunan konsentrasi terjadi karena kerusakan sampel atau karena pengaruh penguapan air dan kandungan senyawa-senyawa volatil seperti minyak atsiri dan asam organik yang mungkin terkandung di dalam sampel. Hal ini akan dijelaskan sebagai berikut. Air akan menguap dalam proses pengeringan, namun hal ini tidak akan
Kemungkinan lainnya dari faktor penguapan adalah asam organik. Senyawa ini larut dalam air dan dapat terekstrak di dalam metanol yang telah difraksinasi dengan kloroform dan n-heksana. Selain itu, asam organik mempunyai titik didih yang rendah hingga mudah menguap (Harborne, 1987). Jika ekstrak mengandung asam organik, maka akan terlihat pita gugus karboksil di dalam spektrum FT-IR. Walaupun pada spektrum terdeteksi gugus karbonil dan hidroksil, kedua gugus fungsional ini bukan merupakan bagian dari gugusan karboksil yang memiliki pita pada 1280 $\mathrm{cm}^{-1}$ sebagai dimer uluran dari C-O. Oleh karena pada kedua spektrum tidak terlihat adanya pita karboksil tersebut dan tidak terdapat senyawa minyak atsiri di dalam sampel, maka dapat diduga bahwa perubahan konsentrasi yang terjadi bukan merupakan akibat penguapan. Hipotesis ini diperkuat dengan keberadaan klorofil di dalam sampel yang terlihat pada

Tabel 1. Perhitungan Po/P dari bilangan gelombang $1111,25 \mathrm{~cm}^{-1}, 1406,63 \mathrm{~cm}^{-1}$, dan $1639 \mathrm{~cm}^{-1}$ pada spektrum FT-IR ekstrak metanol Ulva fasciata segar dan kering matahari

Table 1. Po/P calculation of wavenumber at $1111.25 \mathrm{~cm}^{-1}, 1406.63 \mathrm{~cm}^{-1}$, and $1639 \mathrm{~cm}^{-1}$ in FT-IR spectrum of methanolic extract from fresh and sun dried Ulva fasciata

\begin{tabular}{cccccc}
\hline $\begin{array}{c}\text { Frekuensi/Frequency } \\
\left(\mathrm{cm}^{-1}\right)\end{array}$ & $\begin{array}{c}\text { Log } \\
\text { PoK/PK }\end{array}$ & $\begin{array}{c}\text { Log } \\
\text { PoS/PS }\end{array}$ & $\begin{array}{c}\text { (log PoK/PK)/ } \\
(\log \text { PoS/PS) }\end{array}$ & $\begin{array}{c}\text { Efek perubahan/ } \\
\text { Changing effect }\end{array}$ & $\begin{array}{c}\text { Rasio perubahan/ } \\
\text { Changing ratio (\%) }\end{array}$ \\
\hline 1111.25 & 0.280 & 0.380 & 0.737 & Menurun/Decrease & 26.31 \\
1406.63 & 0.125 & 0.325 & 0.385 & Menurun/Decrease & 61.54 \\
1639.00 & 1.560 & 1.207 & 1.292 & Meningkat//ncrease & 29.25 \\
\hline
\end{tabular}

mempengaruhi perhitungan, karena kedua sampel ekstrak dikeringkan dengan menggunakan freeze dryer (pengering beku). Oleh karena itu, faktor kadar air yang mungkin akan mengganggu serapan gugus hidroksil dapat diabaikan.

Senyawa volatil berupa minyak atsiri, walaupun dari namanya merupakan senyawa yang mudah menguap, namun memiliki titik didih yang cukup tinggi yaitu antara $140-180^{\circ} \mathrm{C}$ untuk kelompok monoterpena dan lebih dari $200^{\circ} \mathrm{C}$ untuk kelompok sesquiterpena (Harborne, 1987). Pada prosedur isolasi minyak atsiri menurut Harborne (1987) diketahui senyawa ini memiliki kepolaran yang rendah yaitu terekstrak di dalam pelarut eter. Manual Milipore (1992) menerangkan bahwa nilai kepolaran eter di bawah kloroform, oleh karena itu ekstrak metanol dari sampel segar maupun kering matahari yang telah difraksinasi oleh $n$-heksana dan kloroform tidak mengandung senyawa-senyawa minyak atsiri, hingga penurunan konsentrasi yang terlihat tidak disebabkan karena penguapan minyak atsiri. spektrum UV-Vis di 674 dan 408 nm (Harborne, 1987). Senyawa ini merupakan senyawa sangat peka terhadap cahaya hingga dapat menjadi sumber pemicu reaksi autooksidasi (Hall \& Cuppett, 1997).

Besarnya energi radiasi sinar matahari pada panjang gelombang $200-400 \mathrm{~nm}$ terlihat pada Tabel 2. Energi radiasi sinar ultraviolet mampu mengeksitasi elektron pada senyawa di dalam rumput laut dan energi minimum yang diperlukan untuk melangsungkan proses reaksi fotokimia adalah sebesar $586 \mathrm{~kJ} / \mathrm{mol}$ (Stanley et al., 1988). Oleh karena itu, radiasi sinar matahari akan mampu menimbulkan reaksi kimia yang mengubah kosentrasi gugus fungsi dan ikatan rangkap dalam sampel selama proses pengeringan.

Hall \& Cuppett (1997) menyatakan bahwa reaksi yang belangsung sebagai akibat dari radiasi sinar ultraviolet pada udara terbuka adalah reaksi fotooksidasi. Reaksi yang terjadi diawali oleh senyawa dalam sampel yang peka terhadap cahaya, misalnya klorofil (S) dengan radiasi ultraviolet.

$$
1 \mathrm{~S}+\mathrm{hv}{ }_{-} 1 \mathrm{~S}^{*} \rightarrow 3 \mathrm{~S}^{*}
$$


Tabel 2. Energi radiasi sinar ultraviolet

Table 2. Radiation energy of ultraviolet light

\begin{tabular}{cc}
\hline $\begin{array}{c}\text { Panjang gelombang/ } \\
\text { Wavelength }(\mathrm{nm})\end{array}$ & $\begin{array}{c}\text { Energi/Energy } \\
(\mathrm{kJ} / \mathrm{mol})\end{array}$ \\
\hline 200 & 598 \\
250 & 479 \\
300 & 399 \\
350 & 342 \\
400 & 299 \\
\hline
\end{tabular}

Sumber/Souces: Stanley, et al. (1988)

Senyawa peka cahaya yang tereksitasi (ditandai dengan *) akan kembali ke keadaan dasar dengan cara mentransfer energinya untuk mengeksitasi triplet oksigen hingga menghasilkan singlet oksigen yang sangat reaktif (Hall \& Cuppett, 1997).

$$
3 \mathrm{~S}^{*}+3 \mathrm{O}_{2} \rightarrow 3\left(\mathrm{O}_{2}^{*}+\mathrm{S}\right)
$$

Singlet oksigen ini akan bereaksi dengan gugusgugus fungsi dan ikatan rangkap dalam sampel selama proses pengeringan berlangsung. Hal yang menarik terlihat pada spektrum FT-IR di bilangan gelombang $1639 \mathrm{~cm}^{-1}$ yang memperlihatkan kenaikan konsentrasi. Hal ini dapat diduga sebagai berikut. Gugus ikatan rangkap dua, yang memiliki densitas elektron tinggi adalah sasaran utama dari reaksi fotooksidasi singlet oksigen. Hal ini dibuktikan dengan tingginya perubahan ikatan rangkap dua terkonjugasi selama proses pengeringan yang terlihat pada spektrum UV-Vis di daerah 240-270 nm. Reaksi yang terjadi pada proses pemecahan ikatan rangkap adalah terbentuknya asam karboksilat seperti pada mekanisme oksidasi ketengikan pada lemak.

$$
\mathrm{R}-\mathrm{C}=\mathrm{C}-\mathrm{R}+\mathrm{O}_{2} \rightarrow 2 \mathrm{R}-\mathrm{COOH}
$$

Dengan adanya singlet oksigen, asam karboksilat ini mungkin terpecah kembali menjadi beberapa turunannya yang salah satu dari pecahannya tersebut dapat berupa karbonil radikal. Hal ini menjelaskan penambahan konsentrasi yang terjadi pada bilangan gelombang karakteristik $1639 \mathrm{~cm}^{-1}$ di spektrum FTIR.

Gugus eter dan karbonil yang memiliki densitas elektron tinggi dalam atom oksigennya dapat bereaksi dengan singlet oksigen. Reaksi fotooksidasi yang terjadi pada eter akan menghasilkan senyawa hidroperoksida dan peroksida.

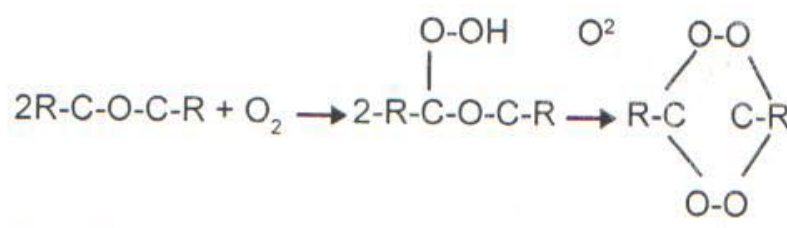

Eter hidroperoksida/ Ether hydroperoxide

Eter peroksida/ Ether peroxide

Pada pemanasan lebih lanjut, senyawa peroksida ini dapat terpecah melalui mekanisme radikal bebas membentuk rantai $\mathrm{R}$ dan gas $\mathrm{CO}_{2}$.

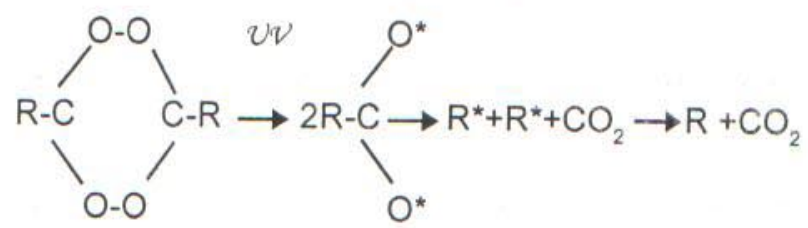

Selain reaksi yang diawali dengan pembentukan singlet oksigen seperti di atas, energi sinar ultraviolet juga mampu memecah radikal bebas senyawa dalam sampel secara langsung. Satu radikal bebas dapat bertanggung jawab sebagai pemicu bagi reaksi berantai radikal bebas (Stanley et al., 1988). Sebagai contoh, selain mengalami mekanisme oksidasi ketengikan oleh singlet oksigen, ikatan rangkap dua juga dapat terpecah karena bereaksi dengan alkil radikal (Stanley et al., 1988).

$$
\begin{aligned}
& U \mathcal{V} \\
& \mathrm{R}^{*}+\mathrm{R}-\mathrm{CH}=\mathrm{CH} \longrightarrow \mathrm{R}-\mathrm{C}-\mathrm{C}^{*}-\mathrm{R}
\end{aligned}
$$

Menurut Stanley et al. (1988), hasil reaksi radikalisasi fotooksidasi yang dipaparkan di atas 
mungkin terurai lagi menjadi beberapa senyawa lain sampai terjadi reaksi penghentian radikal yang meliputi penggabungan dua spesies radikal bebas membentuk hasil reaksi yang mantap yaitu $R$ dan senyawa karbondioksida berupa gas sehingga tidak terdeteksi pada spektrum. Namun hal yang menarik terlihat pada spektrum yaitu terdeteksi bentuk sintesis senyawa baru, dengan terlihat adanya penambahan gugusan karbonil pada sampel. Akan tetapi, kepastian dari hal ini perlu diuji lanjut.

Spektrum juga memperlihatkan bahwa pengaruh pemanasan sinar matahari selama 48 jam tidak menghilangkan sepenuhnya gugus fungsional dari sampel. Akan tetapi, hilangnya sebagian konsentrasi ini akan mempengaruhi uji bioaktivitas yang dilakukan terhadap sampel tersebut jika gugus yang konsentrasinya tereduksi merupakan gugus fungsional yang terlibat dalam keaktifan suatu senyawa. $\mathrm{Hal}$ ini sesuai pernyataan Hashimoto (1979), yang menerangkan bahwa toksisitas dari rumput laut akan terdekomposisi (tidak hilang sepenuhnya) jika diradiasi oleh sinar ultraviolet. Pendapat ini diperkuat oleh Wikanta et al. (2003) yang menemukan bahwa pada uji toksisitas menggunakan metode kematian Artemia salina, toksisitas ekstrak metanol Ulva fasciata berkurang selama proses pengeringan menggunakan sinar matahari. Oleh karena itu, proses yang terjadi sesuai dengan pernyataan Stanley et al. (1988) yang menerangkan bahwa sebagian besar bahan organik akan rusak jika dihadapkan pada udara dan sinar matahari karena proses autooksidasi.

Permasalahan yang lebih lanjut adalah bagaimana menerangkan persamaan matematis yang memperlihatkan massa gugus fungsi tertentu yang hilang dan berubah menjadi gas karbondioksida selama pemanasan berlangsung. Hal ini sulit dilakukan jika hanya berlandaskan data dari spektrum UV-Vis dan FT-IR karena sebuah puncak pada spektrum UVVis dan pita pada spektrum FT-IR dapat merupakan hasil kombinasi dari beberapa interaksi gugus fungsi. Namun, didukung dengan referensi mengenai reaksi fotooksidasi, hasil kualitatif spektrum FT-IR dan UVVis menghasilkan data yang cukup untuk memberikan hipotesis tentang hal yang terjadi selama pengeringan bahan baku menggunakan sinar matahari. Persamaan matematis akan dapat diberikan jika dilaksanakan penelitian lebih lanjut menggunakan spektrometri resonansi magnetik elektron atau menggunakan spektrometri resonansi magnetik inti $\mathrm{H}$ dan $\mathrm{C}-13$. Spektrum proton $\mathrm{H}$ dan $\mathrm{C}-13$ akan memperlihatkan atom karbon tertentu yang berubah gugus fungsinya hingga persamaan matematis dapat dibuat. Jika hipotesis dalam riset ini benar, maka penggunaan spektrometri resonansi magnetik inti $\mathrm{H}$ dan $\mathrm{C}-13$ tersebut akan memberikan bukti-bukti data yang lebih spesifik dalam menerangkan hal yang terjadi selama pemanasan bahan baku menggunakan sinar matahari.

\section{KESIMPULAN DAN SARAN}

Analisis gugus aktif melalui spektroskopi UV-Vis dan FT-IR memperlihatkan bahwa preparasi pengeringan bahan baku rumput laut menggunakan sinar matahari dapat mengubah konsentrasi gugus fungsional di dalam sampel ekstrak rumput laut Ulva fasciata. Oleh karena itu, pada eksplorasi senyawa alami dari rumput laut UIva fasciata, metode preparasi bahan baku menggunakan pengeringan matahari sebaiknya dihindarkan.

Hasil riset ini perlu dilanjutkan dengan penelitian yang menggunakan spektrometri resonansi magnet proton $\mathrm{H}$ dan $\mathrm{C}-13$ untuk menentukan gugus fungsional yang hilang dan disertai dengan uji bioaktivitas terhadap ekstrak dari sampel segar dan kering matahari tersebut.

\section{DAFTAR PUSTAKA}

Anggadiredja, J.T. 2004. Diversity of Antibacterial Subtances from Selected Indonesian Seaweeds. Ringkasan Desertasi. Program Studi Biologi Pascasarjana. Universitas Indonesia. Jakarta. $5 \mathrm{pp}$.

Febles, C., Arias, A., Gil-Rodr, M.C., Hardisson, A. and Sierra, A. 1995. In Vitro Study of Antimicrobiology in Alga Collected from The Coastal of Tenerife. Anuario del Istituto de Estuadios Canaros, 34. Spain. 184 pp.

Hall, C.A. and Cuppett, S.L.1997. Structure activities of natural antioxidants. Antioksidan Methodology. AOCS Press. Champaign, Illinois, p. 167-168.

Harborne, J.B. 1987. Metode Fitokimia-Penuntun Cara Modern Menganalisis tumbuhan. Penerjemah: Padmawinata, K. dan Soediro I. Edisi kedua. Penerbit ITB. Bandung. p. 6-7.

Hashimoto, Y. 1979. Marine Toxin and Other Bioactive Marine Metabolites. Japan Scientific Society Press. Japan. 214 pp.

Milipore Corporation. 1992. Waters Sep Hak Catridge Care and Manual. Waters Chromatography Publications. Milford. 13 pp.

Portito, E. and Reina, G.G. 2001. Screening of Antimicrobial Activities in Red, Green and Brown Macroalgae from Gran Ganaria Spain. International Microbiol. Sping-Verlag \& SEM. Spain. 37 pp.

Silverstain, R.M., Bassler, G.C. and Morril, T.C.1986. Penyelidikan Spektrometrik Senyawa Organik. Penerjemah: Hartomo, A.J. dan A.V. Purba. Edisi Keempat. Penerbit Erlangga. p. 95-105.

Stanley, H.P., Hendrickson, J.B., Cram, D.J. and Hammond, G.S. 1988. Kimia Organik. Penerjemah: Joedodibroto, R. dan Hadiwidjoyo, S.W.P. Jilid 2. Edisi keempat. Penerbit ITB Bandung. p. 953-985.

Vitor, J.M., Calvanho, F.F.U., Freitas, S.M. and Vania, M.M. 2002. Antibacterial activity of extracts from six 
macroaigae from northern Brazilian. Brazilian Journal of Microbiology. 33(4): 2 .

Wikanta, T. Hastarini, E, Januar, H.I., Fawzya, Y.N., Amini S. Irianto, H.E., Yunizal, dan Sugiono. 2003. Laporan Teknis Riset Ekstraksi Senyawa Bioaktif dari Biota
Perairan. Pusat Riset Pengolahan Produk dan Sosial Ekonomi Kelautan dan Perikanan. Jakarta. 34 pp Willard, H.H., Merrit, L.L. Jr and Dean, J.A. 1974 Instrumental Methods for Analysis. Fifth Edition. D Val Nostrand Company. New York. p. 108 \& 172 